\title{
PARAMETERS OF SEMICONDUCTING GAS SENSORS ACCEPTABLE FOR NON-INVASIVE EARLY DETECTION OF WOUND INFECTIONS *
}

\author{
A. Galdikas ${ }^{\text {a }}$, Ž. Kancleris ${ }^{\text {a }}$, A. Olekas ${ }^{\text {a }}$, D. Senuliené ${ }^{a}$, V. Strazdienè ${ }^{\text {a }}$, A. Šetkus ${ }^{\text {a }}$, \\ R. Bagdonas ${ }^{\mathrm{b}}$, and R. Rimdeika ${ }^{\mathrm{b}}$ \\ a Semiconductor Physics Institute, A. Goštauto 11, LT-01108 Vilnius, Lithuania \\ E-mail: setkus@pfi.lt \\ ${ }^{\mathrm{b}}$ Kaunas Medical University Hospital, Eiveiniu 2, LT-50009 Kaunas, Lithuania
}

Received 27 June 2005

\begin{abstract}
Method of multiexponential decays is used for approximation of the resistive sensor response to steep change in gas composition in the atmosphere. The response of tin and indium oxide thin film sensors is described by a set of the parameters that are included into the output database of the sensor array. The dependence of these parameters on the rates of the surface chemical processes is discussed. The output database is visualised using an original method of a two-dimensional graphical representation that is introduced as a "portrait" of smell. Suitability of these graphical images for identification of the infected substances and infection type is studied. Based on visual inspection of the images, the contamination of chicken meat with bacteria is detectable within several hours after the intentional infection. Capabilities to distinguish between the clinical infections of wounds and to diagnose the infection by smell are studied.
\end{abstract}

Keywords: metal oxide, electrical properties, odour detection, diagnostics of infection

PACS: 73.25+i, 73.90+f, 81.05.Rm, 81.15.Cd

\section{Introduction}

It is commonly accepted now that an electronic nose (EN, e-nose) is a qualitative, low-cost, real-time, and portable method for reliable, objective, and reproducible measures of volatile compounds and odours. An EN-based device typically includes three main parts, namely gas sensors, interface electronics, and a system for sophisticated data processing. In the EN system, a collection of chemical sensors is typically used. Each sensor in EN measures a different property of the sensed chemical. Until now, the response to chemical interaction was obtained and studied in metal oxide semiconductors, conductive polymers, surface acoustic wave devices, bulk acoustic wave devices, quartz crystal microbalances, chemical field effect transistors, fibre optic sensors. It has been commonly recognised that the metal oxide sensors are the most acceptable type of sensors for commercial systems because these sensors are cheap, simple in use, and acceptable for miniaturisation and integration in a single chip. In addition, based on the well-developed

\footnotetext{
* The report presented at the 36th Lithuanian National Physics Conference, 16-18 June 2005, Vilnius, Lithuania.
}

technology, the sensitivity and selectivity of these sensors to gas are easily modified and well-controlled. The modern approach in the EN development is based on an array of sensors that are not selective and not highly specific to a particular gas but have a broader response to various gases. This approach has been inspired by novel understanding of biological olfactory systems and it aims to reduce the requirements on both the number and the selectivity of the sensors. It greatly facillitates the development of a highly flexible and widely applicable EN system capable to recognise a large number of volatile compounds having features that are defined by special training of the EN and stored in the library of the EN. In spite of that, it has been commonly recognised now that it is too complicated to develop an EN for general purposes at the present stage. Therefore, the array, signal processing, the database of the outputs, and the construction of the system have to be optimised for each practical application before the EN can be used.

In an EN, raw signals from an array of the sensors are usually pre-processed before the database of signals is analysed with the mathematical tools such as principal component analysis (PCA) or neural network 
(NN). The aim of the pre-processing is to extract the most useful information from the entire database of the output signals obtained from an array of gas sensors. Both static and dynamic responses of the sensors could be used to build up an input database for the signal analysis. If the dynamic response is recorded, large number of data points is collected in the output database of the sensors. Before the recognition technique is applied, the signals are usually pre-processed with the aim to reduce the volume of the data. In spite of the fact that pre-processing of transients is more complicated procedure than measurement of the baseline signals of steady-state response, the loss of useful information included in the dynamic response seems evident. Possibility to reveal much more features of an odour stimulates the studies of the response kinetics in various scientific groups [1-7]. This additional information is supposed to improve the capabilities to recognise the odours by the EN.

Numerous attempts have been made to use EN in recognition of the odours in the headspace air of food and drink (e.g. see references in [10]). These ENs were mainly based on metal oxide and conductive polymer resistive gas sensors. Evaluation of the quality and freshness of the foodstuff is related to the detection of the food spoilage and, consequently, to the monitoring of the growth of bacteria in the organic substances. It was found that the EN is able to recognise the presence of bacteria in the substance and even to discriminate among different types of bacteria (see e.g. [8-12]). Now there is a great interest in the clinical application of an EN mainly because of its ability to diagnose illness. It is well known that certain diseases are associated with characteristic smells. There is even a supposition that the human wounds emit individual mixtures of the volatile substances dependent on the type of infection.

Recently we have proposed a method enabling the approximation of kinetics of the resistance response by multiexponential decays $[5,6,8]$. Based on this method, the dynamic response to an injection of gas is described by a certain number of parameters. If the injection of gas is strictly controlled, the parameters of response are determined by the dynamics of the gassurface interaction in the sensors. Since several parameters are defined for single sensor, the database of the sensor outputs is improved by important information without any increase in the number of sensors.

Present report is focused on the analysis of kinetics of the resistance response to a steep change in chemical composition of the atmosphere. The response kinetics is studied in thin film tin and indium oxide based gas sensors. Original method for graphical visualisation of the output signals of an array of sensors is described in detail. Possibilities to distinguish between the noninfected and bacteria infected organic materials is studied. Applicability of the method to discriminate among different types of wound infection is discussed.

\section{Relations to the response model}

General aspects of the response mechanism are well known for the metal oxide based semiconducting gas sensors. Based on this, the relationship between the parameters of surface chemical processes and the electrical properties was theoretically described for the gas sensitive films in [13]. Considering a single type of the target gas and one type of the chemisorbed oxygen, the resistance change $R(t)$ induced by the gas in polycrystalline films might be approximated by the formula

$$
\begin{aligned}
\frac{R(t)}{R(0)}= & \exp \left\{Z^{2} \Theta_{A 0}^{2}\right. \\
& \left.\times\left[\left(1-\eta_{1} \frac{\Xi_{A B}}{\Theta_{A 0}} \frac{1-\exp (-t / \tau)}{1-\eta_{2} \exp (-t / \tau)}\right)^{2}-1\right]\right\}
\end{aligned}
$$

In (1), $\Theta_{A 0}$ is the initial coverage of the surfaces with the chemisorbed oxygen species, $Z$ and $\Xi_{A B}$ are the parameters related to the concentration of impurities in the volume and the densities of chemisorption centres on the surfaces. The parameters $\eta_{1}$ and $\eta_{2}$ include the rates of the surface processes and characteristics of the gas (e.g. the mass of the gas molecule). Time constant $\tau$ corresponds to the response time that characterises the rise of response after the injection of the gas. Details of description might be found in [13].

It might be expected that the description (1) will be more complicated if the co-adsorption effect and a few chemisorbed oxygen species are included in the model. In spite of the lack of such a thorough analysis of the processes, the phenomenological description (1) suggests general ideas about the information that might be extracted from the response signal of the gas sensors. The signal is influenced by the changes in the bulk impurities (parameter $Z$ ) or the chemisorption centres $\left(\eta_{1}, \eta_{2}\right.$, and $\left.\Xi_{A B}\right)$ or the density of chemisorbed oxygen $\left(\Theta_{A 0}\right)$. It is evident that the sensor signal contains mixed information about the properties of the layer and the features of chemical interaction. The parameters of the layer and the reaction might be evaluated by fitting the theoretical transient (1) to the experimental results. It is evident that this method is too complicated for 
practical pre-processing of the signals in an EN. In addition, the parameters related to the properties of layer are not useful for the featuring of odours. The influence of redundant parameters on the development of odour features might be reduced if the time constants (or related parameters) are used to build up the database.

The entire length of the transient of response to the gas usually consists of the rise and recovery intervals. It follows from the phenomenology in [13] that the rise (or response) time is mainly determined by the time constant $\tau$ included in (1). Within the phenomenological model [13], this time constant might be described by the following formula:

$\frac{1}{\tau_{g}}=\left[\left(\alpha_{B} S_{B}+\beta_{B}+\nu_{A B} \Theta_{A 0}\right)^{2}-4 \nu_{A B} \alpha_{B} S_{B}\right]^{1 / 2}$.

In (2), $g$ indicates the interval of rise and, consequently, $\tau \equiv \tau_{g}$. Parameter $\alpha_{B}$ is the rate of incident flux and $S_{B}$ is the sticking probability for target gas molecules, $\beta_{B}$ is the desorption rate for target gas, $\nu_{A B}$ is the rate for bimolecular interaction between the chemisorbed target gas and oxygen species. In general, the recovery time differs from the rise time. As it follows from [13], the time constant $\tau_{\mathrm{c}}$ that characterises the recovery of a sensor to the clean-air conditions might be described by the following formula:

$$
\frac{1}{\tau_{\mathrm{c}}}=\beta_{B}+\nu_{A B} \Theta_{A 0} .
$$

It is clear that the difference between $\tau_{g}$ and $\tau_{\mathrm{c}}$ is determined by the presence or absence of the chemisorption process. It is interesting to note that the rise time constant $\tau_{g}$ is dependent on the amount of gas in the atmosphere $\left(\alpha_{B} \sim P_{\text {gas }}\right)$ while the recovery time constant $\tau_{\mathrm{c}}$ is independent of the gas amount to which the sensor was exposed. In contrast to $\tau_{\mathrm{c}}$, the signal $R(t) / R(0)$ depends on the gas amount because the parameters $\eta_{1}, \eta_{2}$, and $\Xi_{A B}$ of the chemisorption centres include the coverage of surfaces with the target gas.

Finalising it might be concluded that the rise time of response to a gas contains information about the target gas regarding the gas amount in the atmosphere, the incident flux, and the chemisorption parameters (see definition of $\alpha_{B}$ in [13]). The recovery time $\tau_{\mathrm{c}}$ is also defined by the specific parameters $\beta_{B}$ and $\nu_{A B}$ of the target gas, but these parameters do not provide quantitative information about the target gas. Since the time constants are easily obtainable from the measured transients, it seems reasonable to expect that the dataset of such parameters will be correlated with specific properties of the volatile compounds and specific aspects of interaction between these compounds and the sensor surfaces. But in practice the method for extraction of phenomenological rates of the surface reaction from the measured results is highly complicated. Consequently, these parameters can hardly be used for the featuring of odours, while the understanding of effectiveness of the transient approach can be improved considerably.

\section{Experimental and analysis methods}

\subsection{Gas sensors and flow control}

The sensor array was composed of the homemade sensors based on tin and indium oxides. The gas sensitive films were deposited by a dc magnetron sputtering on an insulating substrate with thin film thermometer and thin film heater. These two elements of the sensors were used to stabilise individual temperature for each sensor. The surfaces of the gas sensitive layers were modified with a post-growth deposition of the metallic impurities such as $\mathrm{Pt}, \mathrm{Cu}$, and $\mathrm{Ag}$. Details of the sensor technology are described in our previous reports (e. g. $[5,6])$. In addition to the homemade sensors, one standard sensor TGS800 produced by Figaro was included in the array as a reference sensor for signal comparison.

A few arrays were composed of 6-13 sensors. The arrays were mounted in a test chamber with a controlled flow of synthetic air. The flow rate was constant and typically equal to $200 \mathrm{ml} /$ minute. The sensors were periodically exposed to the volatile constituents released from the organic substances stored in a glass vessel. A steep change in gas composition of the gas flow was produced by an automatic two-flow control system. In the system, two flows with similar flow rates were produced in two parallel channels. In one of the channels only clean air was flowing, while the same air in another channel carried some fixed amount of the target gas. Relative humidity of the air was similar in both channels and typically equal to $50 \%$. The switching between the flow of clean air and that of the target smell produced a steep change of gas composition in the test chamber with the sensors. The time-span of the smell pulse was about 12 minutes while that of the clean airflow lasted about 20 minutes. Details on the gas control might be found in our previous reports (e. g. [8]).

The dc voltage drop that is proportional to the electrical resistance was measured for each of the sensors included in the array. The time dependence of the electrical signal was scanned at the rate of one point per 


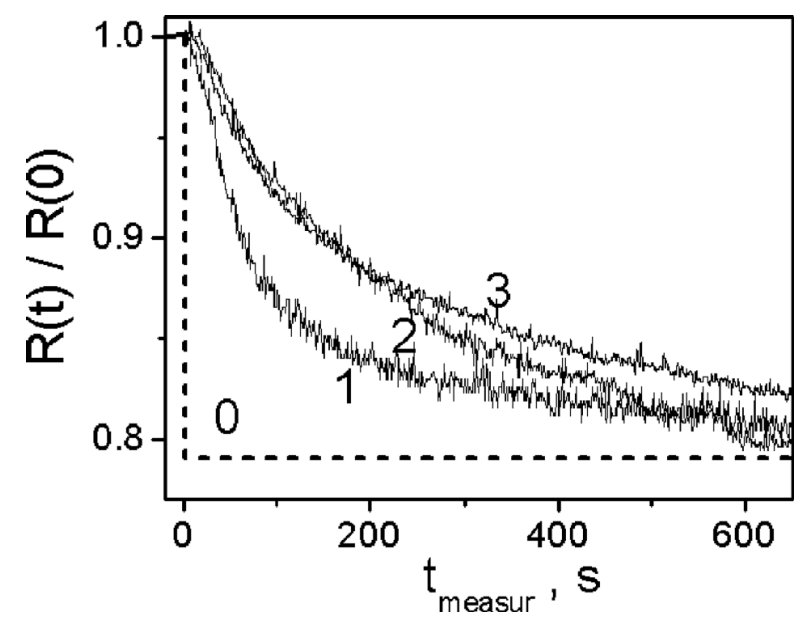

Fig. 1. Time dependences of the resistance response of three tin oxide gas sensors $\left(1-\mathrm{TGS} 800,2-\mathrm{Pt} / \mathrm{SnO}_{2}, 3-\mathrm{Ag} / \mathrm{Pt} / \mathrm{SnO}_{2}\right)$ exposed to the smell of fresh chicken meat.

second for each of the sensors in the array. Typical transients measured during the tests are illustrated in Fig. 1. The results are presented for three of the sensors used in the tests.

\subsection{Smell samples}

Two types of the smell samples were probed in present study. The first type of the smell was blown from the swabs with bacteria. The samples of the discharge from wounds were taken in a hospital. The wounds with a definite type of infection were tested. The type of bacteria was known from the microbiological tests. The samples were as follows: Acinetobacteria lakmanii, Enterococus faecalis (E. faecalis), Stafilococus aureus (S. aureus), and Streptococus pyogenes (S. pyogenes). The swabs were protected with coverage of the growth culture and placed in a glass vessel connected to the two-flow system during the tests. In the second type of the smell tests, fresh chicken mince was intentionally infected with bacteria. Two types of the infection were used: Pseudomonas mirabilis and Listeria monocytogenes. Several portions of the same chicken mince were prepared for the tests including non-infected and infected with individual type of bacteria. The samples were put into individual glass vessels that might be connected to the flow-control system during the tests. In both cases, a stream of the synthetic air was let to flow through the vessel at a constant rate of about $35 \mathrm{ml} /$ minute. In some special experiments in which the dependence of response on the intensity of the smell was studied the flow was varied from 10 to $50 \mathrm{ml} /$ minute.

\subsection{Analysis of the transients}

The analysis of the response kinetics was based on the approximation of the transients by the multiexponential decays, as in $[8,13]$. According to this approach, the resistance change is usually described by

$$
\frac{R(t)}{R(0)}=\left(1-\frac{R(\infty)}{R(0)}\right)+\sum_{i=1}^{M} a_{i} \exp \left(-t / \tau_{i}\right)
$$

with $a_{i}$ as weight coefficient and $\tau_{i}$ as a time constant for the $i$ th exponential component. In our present study, the approximation with multiexponential decays is employed for evaluation of the time constants that are described by the phenomenological model (2). The use of this approach is based on the understanding that the number of variables in the description of resistance response (1) is too large. In addition, it was proved in [13] that the resistance change (1) might be replaced by a sum of the exponential terms (4) if the signals are comparatively small $(\mathrm{R}(\mathrm{t}) / \mathrm{R}(0) \ll 1)$. Based on the analysis of the formula (1) (see e. g. [13]), it might be demonstrated that the longest time constant in (4) is equal to the rise time constant (2), $\tau_{1} \equiv \tau_{g}$. The weight coefficients $a_{i}$ are described by some sophisticated combination of parameters included in (1), but the exact formulas are not the subject of the present study. It is only interesting to note here that the weight coefficients are highly sensitive to the partial pressure of the target gas, $a \sim p^{2}$.

For the multiexponential analysis, an integration method originally proposed by Tittelbach-Helmrich [14] was used. Different methods of the analysis were compared in [15]. Based on the selected integration method, an original pre-processing program was developed. In it, two least squares problems were solved using the singular value decomposition (SVD) procedure, and the roots of polynomial were found using the Muller's method [16]. In the practical procedure of signal analysis we performed the calculations by increasing the number of components extracted from the transient until the complex roots of polynomial were found. The procedure was also terminated if negative components were extracted. After the signal analysis, a collection of pairs of the parameters $\left\{\tau_{i}, a_{i}\right\}$ was obtained for each of the sensors in the array. Time constants and weight coefficients for each object were plotted in the $2 \mathrm{D} \tau$-charts. The method is described in the next subsection. The advantages and problems of the signal pre-processing are discussed in our previous report [8]. 


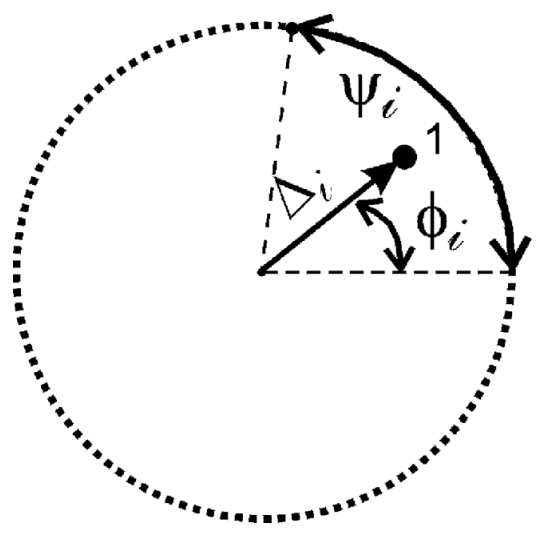

Fig. 2. Visualisation of the response transient approximated by the exponential decays in $2 \mathrm{D} \tau$-graphical image. The point 1 represents an exponential component in the two-dimensional plot: $\Delta_{i}=1 / \tau_{i}$ is the length of the vector, $\phi_{i}=M^{-1} \arcsin a_{i}+\psi_{i-1}$ is the rotation angle for the vector; a sector attributed to the $i$ th sensor $\psi_{i}=\mathrm{i} 2 \pi / M$, and $M$ is the number of sensors in an array.

\subsection{Graphical presentation of responses}

The characteristic parameters of the transients are used for the composition of a graphical representation of the sensor outputs that might be visually inspected. Visualisation of the response signals was also found useful for the investigations by the authors of other studies (e.g. $[17,18])$.

Based on the approximation described in Subsection 3.3, each transient was characterised with a few pairs of related parameters, namely, the time constant $\tau_{i}$ and weight coefficient $a_{i}$. A point in a two-dimensional plot represented individual pair of the parameters. Reciprocal time constant was assumed to be the length of the vector, while the weight coefficient defined the sine of the rotation angle $\phi$ for the vector. The circle is divided into areas, the number of which is equal to the number of sensors included in the array. The zero edge for the segment attributed to the $i$ th sensor is defined by the basic rotation angle $\psi_{i}=\mathrm{i} 2 \pi / M$ for the entire segment. Principles of the visualisation are illustrated in Fig. 2.

Each pair $\left\{\tau_{i}, a_{i}\right\}$ was assumed to be the coordinates of a point in a two-dimensional plot in Fig. 2. In the plot, collection of a few points is representing the parameters of approximation of the transient. In general, the time constants $\tau_{i}$ are the phenomenological parameters related to the rates of chemical reactions on the surfaces of sensors. Consequently, a change of a dominant compound in the target smell must induce a change in the constants $\tau$. Such a change would be visualised by a change in the distance from the centre at which the corresponding point is plotted. The weight coefficients $a_{i}$ are dependent on the intensity of the target smell, i. e. on the concentration of the volatile compounds in the smell. A change in the concentration would be related to a change in the rotation angle for the vector in the plot. It seems obvious that the transient response of even one sensor could provide several points in the two-dimensional images of the target smell.

\section{Results and discussions}

\subsection{Human wound infection}

Typical 2D $\tau$-images of the smell for the samples with bacteria from the human wounds are shown in Fig. 3. The output data in the images was collected from an array of 12 sensors. In the figure the same type of points denotes the pair of parameters $\left\{\tau_{i}, a_{i}\right\}$ obtained from an individual sensor for particular $i$. These points are connected by a closed line which outlines some shape. This shape is included in the image as an individual layer. Several layers were collected in Fig. 3. The layer marked as 1 and 2 corresponds to particular $i$ in (4). Special layer labelled by $S$ is introduced in our graphical representation of the results. This layer $S$ represents the stationary signals of the sensors. This stationary signal corresponds to the term within the brackets on the right side in (4). Each point in the figure represents an individual stationary response of a separated sensor in the array. The contour of this layer $S$ represents a set of the stationary response signals of all the sensors included in the array and demonstrates the standard approach of the stationary signals that is still used in the commercial electronic noses. The multilayer arrangement of the profiles produces the $2 \mathrm{D} \tau$-images of the smell.

The $2 \mathrm{D} \tau$-images are compared for three types of the bacteria in Fig. 3. The profiles that visualise the exponents of the same $i$ (the same label in Figs. 3(a-c)) might be easily distinguished one from another. The shapes with labels 1 and $S$ include the points attributed to all the sensors in the array while only some of the sensors are represented by the points in the layer 2 in Fig. 3. The $2 \mathrm{D} \tau$-images seem to be individual for each type of bacteria.

\subsection{Infected chicken meat}

In Figs. 4(a-c), the $2 \mathrm{D} \tau$-images are illustrating the smell of the chicken meat, including the sample of fresh clean meat (Fig. 4(a)) and the samples of the same meat infected with Listeria monocytogenis (Fig. 4(b)) and Pseudomonas mirabilis (Fig. 4(c)). These three images have summarised the ageing of the meat analysed 


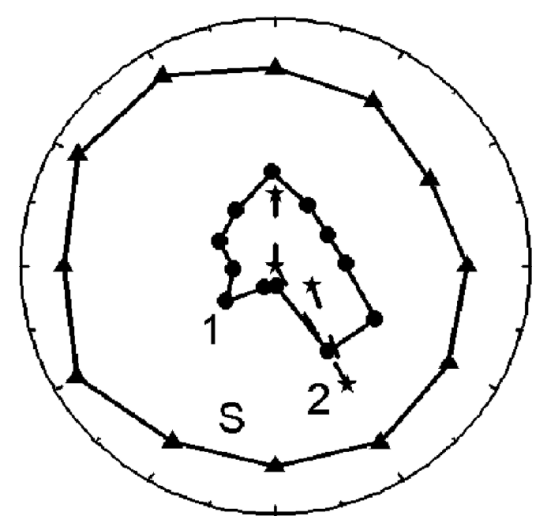

(a)

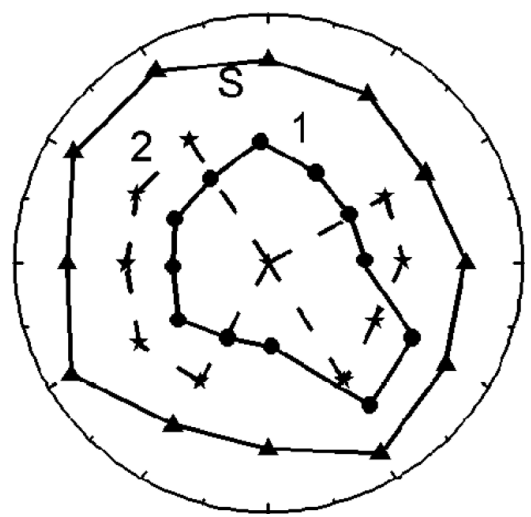

(b)

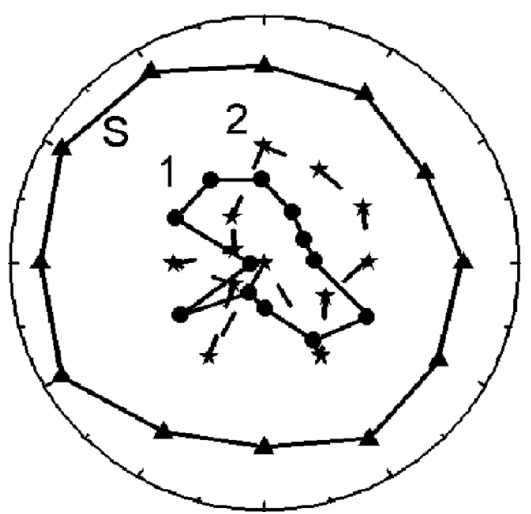

(c)

Fig. 3. Visualised response transients for the array of 12 sensors exposed to the growth substances with different bacteria: (a) Streptococus pyogenes, (b) Enterococus faecalis, (c) Acinetobacteria lakmanii.

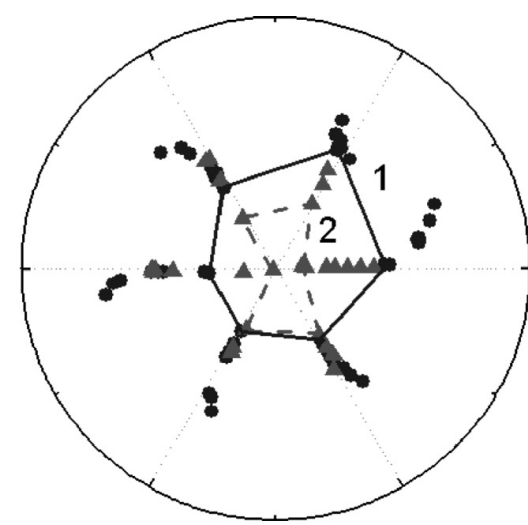

(a)

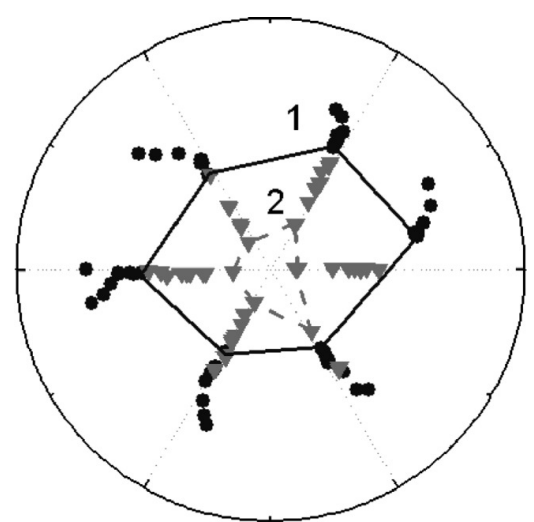

(b)

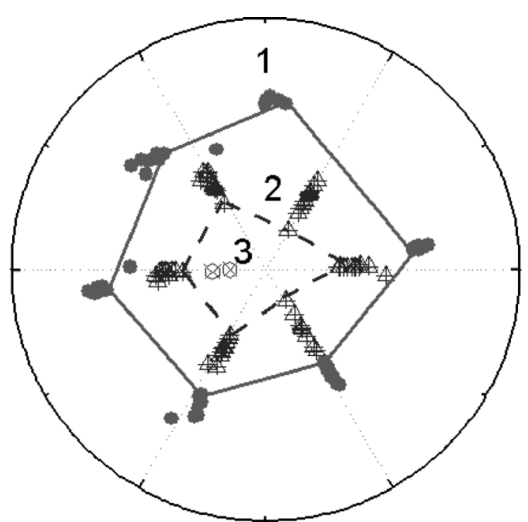

(c)

Fig. 4. Visualised transients for the array of 6 sensors exposed to a smell of chicken at different periods (closed lines indicate different layers of the first measurement at 4 hours) after the preparation: (a) non-infected and infected with (b) Listeria monocytogenis, (c) Pseudomonas mirabilis.

during the long-term test carried out for the period of about 50 hours. Each of the samples was periodical probed with the array of 6 sensors at the intervals of about 6-8 hours. Between the measurements, each of the meat samples was stored at $+4{ }^{\circ} \mathrm{C}$ in a refrigerator in an individual glass vessel that was connected to the measurement system during the tests. The $2 \mathrm{D} \tau$-image was composed for each of the measurement performed during the entire period of the long-term test. The series of $2 \mathrm{D} \tau$-images obtained for the individual sample of meat were combined into a compound image that summarised the information about the ageing of the individual sample of meat.

The infected chicken meat might be distinguished from the non-infected one after 6 hours following the intentional infection by the visual inspection of images in Figs. 4(a-c). The layers of the corresponding $2 \mathrm{D} \tau$-images are made visible by the lines in Fig. 4 . It should be noted that only the layers that represent the exponential terms of the first and the second order are included into the images. The layers that correspond to the stationary signals of sensors are omitted in those illustrations because these signals seemed much less specific than the other layers, as in Fig. 3. It should also be noted that the difference between the meat samples might be traced in the $2 \mathrm{D} \tau$-image by a visual inspection at any period of the long-term tests.

Whenever the headspace smell of the sample meat was analysed with the standard gas chromatography, the difference was not traced between the samples within a similar period after the infection. The presence of bacteria was detected by the gas chromatography only about a few days later (depending on the storage conditions). The results of these tests will be discussed in forthcoming reports. 


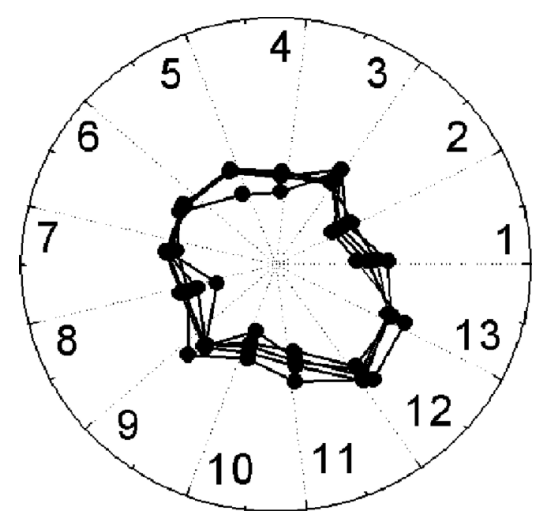

(a)

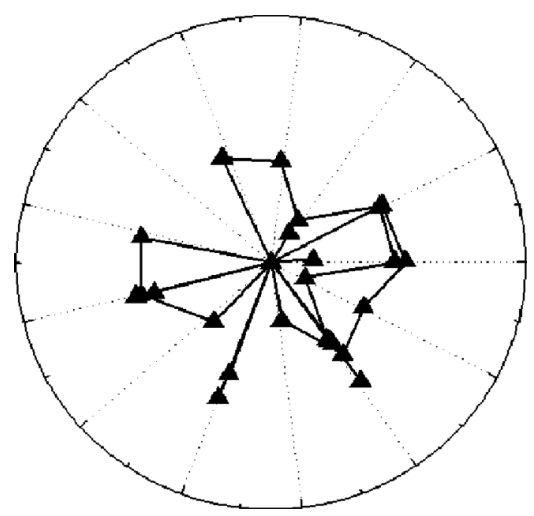

(b)

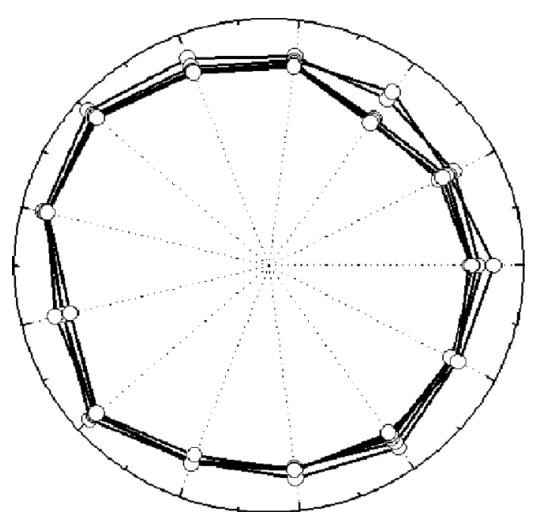

(c)

Fig. 5. Reproducibility of the $2 \mathrm{D} \tau$-images: the images are split into individual layers according to the terms of (a) the component number $i=1$, (b) $i=2$, and (c) stationary signal. The response transients measured by the array of 13 sensors exposed repeatedly to the growthsubstance with Stafilococus aureus.

\subsection{Limits of the transient analysis}

The experimental signals were usually interfered with a noise. The exponential approximation should evidently be dependent on the noise level. We have performed statistical tests to determine the largest noiseto-signal ratio (NSR) at which the method developed by us reliably separates the components of the transient. Relative standard deviation of $10 \%$ for the time constant and $15 \%$ for the weight coefficient has been accepted as the criterion in the numerical tests. Twoand three-component transients were analysed. For the transients detected in our study, the NSR typically was about $\left(10^{-3}-10^{-2}\right)$. From the modelling tests it was concluded that two or even three exponential components could be extracted with reasonable accuracy from typical transients detected in our experiments. Details of these tests are presented in our previous report [8]. The influence of the noise on the results of analysis might also be understood from the results illustrated in Fig. 5 that are discussed in the Subsection 4.4.

\subsection{Reproducibility of the images}

We performed additional investigation of the reproducibility of the $2 \mathrm{D} \tau$-images. The transients of response to the target smell of the same substance were repeatedly measured in sequence without an intentional delay. Typical results of this experiment are illustrated in Fig. 5. Six measurements were performed at analogous conditions during about three hours. The profiles that correspond to different $i$ are shown in separate plots. The results were obtained by exposing the array to the headspace smell of the swab with Stafilococus aureus obtained from an infected wound. Based on the visual inspection of Figs. 5(a) and (c), the layers of $i=1$ and the stationary signals that do not vary so much might be accepted as the same.

It is clearly seen from Fig. 5(b) that the image for $i=2$ has varied too much from measurement to measurement and, consequently, can not be used for the reliable recognition of bacteria by visual inspection. The variation in the shape of this layer might be explained by small magnitudes of the weight coefficients in the exponential terms for $i=2$. The magnitudes of these coefficients are less than the magnitude of the coefficients for $i=1$ by the factor of about 5-10. This ratio is very close to the limiting value of the amplitude ratio of the exponents that may be extracted from the transients with the NSR characteristic to our experiments. Therefore, the influence of accidental changes occurring in the target substances due to some uncontrollable processes as well as the influence of the noise can be accepted as the reasons of observed differences between the images in Fig. 5(b).

On the one hand, our experiments with the synthetic atmosphere containing $\mathrm{H}_{2}$ gas demonstrate that when the gas content is strictly controlled even three reproducible pairs of parameters $\left\{\tau_{i}, a_{i}\right\}$ have been extracted from the experimentally measured transients [19]. On the other hand, it seems reasonable to suppose that the composition of atmosphere is not completely controlled when the sensors are exposed to the headspace smell of organic substances. In this case, the release of volatile components from the substances might sufficiently vary due to some reasons (e.g. outbreak of a bubble from the substance). 


\section{Conclusions}

Phenomenological parameters that describe the kinetics of response of the metal oxide sensors to a steep change in gas composition were used as the variables for the description of features of a target smell. Taking into account the phenomenological model of the response mechanism, the rise and the recovery intervals in the transient were related to the rate parameters of chemical interaction on the surfaces of sensors. It was demonstrated that the rise of response contains information about the flux of molecules while the characteristics of desorption and bimolecular interaction on the surfaces are included in both parts (the rise and recovery) of the transient. The magnitude of signal during the recovery depends on the exposure to gas while the time constant of the sensor recovery to the state of clean air is independent on the amount of target gas that has induced the rise of response.

Based on the phenomenological parameters, original two-dimensional plots were composed for the visual inspection of the smell features. The method was applied for the comparison of organic substances infected with individual type of bacteria.

It might be summarised from these studies that the $2 \mathrm{D} \tau$-images are in general reproducible in the tests repeated during some fixed period under unchanged conditions. In the case of organic materials, the reproducibility seems to be restricted by the ageing of the target samples. Even a delay of an hour might be significant in the tests with the meat or with the grown bacteria cultures. At least a quantitative difference was obtained between the response signals of the sensors exposed to the same organic sample in the next run about an hour later. The difference was much more significant for the tests performed 10-14 hours after the first run. In this case, the set of kinetic parameters obtained for the same sensor was qualitatively different from the initial one. It was concluded that the method was highly effective for the comparative analysis of the smell features while the absolute recognition of a smell requires a thorough analysis of the changes related to the ageing of the target material.

\section{Acknowledgements}

Authors are grateful to Prof. Giorgio Sberveglieri and his group (University of Brescia, Italy) for the sensors that were granted to us. We acknowledge the assistance of Prof. P.R. Venskutonis from Kaunas Univer- sity of Technology in getting the samples of an infected meat.

\section{References}

[1] E. Llobet, J. Brezmes, X. Vilanova, and J. Sueiras, Qualitative and quantitative anlysis of volatile organic compounds using transient and steady-state responses of tick-film tin oxide gas sensor array, Sens. Actuators B 41, 13-21 (1997).

[2] D. Baranauskas, A. Galdikas, A. Mironas, A. Šetkus, and D. Zelenin, Odour identification system based on transient response of one semiconductor gas sensor, Lithuanian J. Phys. 37, 147-154 (1997).

[3] R. Gutierrez-Osuna, H. Troy Nagle, and S.S. Schiffman, Transient response analysis of an electronic nose using multi-exponential models, Sens. Actuators B 61, 170-182(1999).

[4] T. Eklöv, P. Mårtensson, and I. Lundström, Selection of variables for interpreting multivariate gas sensor data, Anal. Chim. Acta 381, 221-232 (1999).

[5] A. Galdikas, A. Mironas, D. Senulienè, and A. Šetkus, Specific set of the time constants for characterisation of organic volatile compounds in the output of metal oxide sensors, Sens. Actuators B 68, 335-343 (2000).

[6] A. Galdikas, A. Mironas, D. Senuliene, V. Strazdiene, A. Setkus, and D. Zelenin, Response time based output metal oxide gas sensors applied to evaluation of meat freshness with neural signal analysis, Sens. Actuators B 69, 258-265 (2000).

[7] C. Distante, M. Leo, P. Siciliano, and K.C. Persaud, On the study of feature extraction methods for an electronic nose, Sens. Actuators B 87, 274-288 (2002).

[8] A. Galdikas, Ž. Kancleris, D. Senulienè, and A. Šetkus, Influence of heterogeneous reaction rate on response kinetics of metal oxide gas sensors: Application to the recognition of an odour, Sens. Actuators B 95, 244251 (2003).

[9] J.W. Gardner, Hyun Woo Shin, and E.L. Hines, An electronic nose system to diagnose illness, Sens. Actuators B 70, 19-24 (2000).

[10] C.M. McEntegart, W.R. Penrose, S. Strathmann, and J.R. Stetter, Detection and discrimination of coliform bacteria with gas sensor arrays, Sens. Actuators B 70, 170-176 (2000).

[11] N. Magan, A. Pavlou, and I. Chrysanthakis, Milksense: A volatile sensing system recognises spoilage bacteria and yeasts in milk, Sens. Actuators B 72, 2834 (2001).

[12] M. Holmberg, F. Gustafsson, E.G. Hornsten, F. Winquist, L.E. Nilsson, L. Ljung, and I. Lundstrom, Bacteria classification based on feature extraction from sensor data, Biotechnol. Tech. 12, 319-324 (1998).

[13] A. Šetkus, Heterogeneous reaction rate based description of the response kinetics in metal oxide gas sensors, Sens. Actuators B 87, 348-359 (2002). 
[14] K. Tittelbach-Helmrich, An integration method for the analysis of multiexponential transient signals, Meas. Sci. Technol. 4, 1323-1329(1993).

[15] A.A. Istratov and O.F. Vyvenko, Exponential analysis in physical phenomena, Rev. Sci. Instrum. 70, 12331257 (1999).

[16] W.H. Press, S.A. Teukolsky, W.T. Vetterling, and B.P. Flannery, Numerical Recipes in $C$ (Cambridge University Press, Cambridge, 1994) p. 120.

[17] T. Maekawa, K. Suzuki, T. Takada, T. Kobayashi, and
M. Egashira, Odor identification using $\mathrm{SnO}_{2}$-based sensor array, Sens. Actuators B 80, 51-58(2001).

[18] J. Mizsei and S. Ress, Chemical images by artificial olfactory epithelia, Sens. Actuators B 83, 164-168 (2002).

[19] A. Šetkus, C. Baratto, E. Comini, G. Faglia, A. Galdikas, Ž. Kancleris, G. Sberveglieri, and D. Senulienè, Influence of metallic impurities on response kinetics in metal oxide thin film gas sensors, Sens. Actuators B 103, 448-456 (2004).

\title{
PUSLAIDININKINIU DUJU JUTIKLIŲ PARAMETRAI, TINKAMI ANKSTYVAJAM NEINVAZINIAM ŽAIZDŲ INFEKCIJOS APIBŪDINIMUI
}

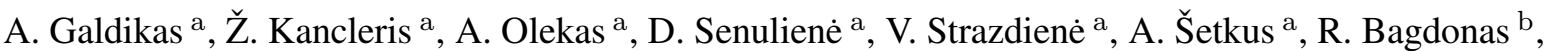 \\ R. Rimdeika ${ }^{b}$ \\ ${ }^{a}$ Puslaidininkiu fizikos institutas, Vilnius, Lietuva \\ ${ }^{\mathrm{b}}$ Kauno medicinos universiteto klinikos, Kaunas, Lietuva
}

\section{Santrauka}

Tirtos galimybès identifikuoti bakterini užkrètimą pagal varžinių dujų jutiklių atsaką i lakiuosius produktus, išsiskiriančius iš užkrèstosios terpès. Tuo tikslu plonasluoksnių alavo ir indžio oksido jutiklių aplinkoje yra staigiai pakeičiama atmosferos sudètis. Atsako ị ši pokytį laikinė priklausomybẻ aprašyta daugiaeksponenčio aproksimavimo metodu ir surasti būdingieji parametrai. Dujų jutiklių komplekto atsakas apibūdintas rastuju eksponenčiu parametru rinkiniu, iš kurio sudaroma šio atsako duomenu bazè. Ap- tarta tų parametru priklausomybė nuo cheminių vyksmų, vykstančiu jautriojo sluoksnio paviršiuje, spartos. Taikant originalu metodą, iš atsako duomenu bazès sudarytas dvimatis grafikas, kuris pavadintas "kvapo atvaizdu". Nagrinèta, kaip šie grafiniai atvaizdai tinka organinių medžiagų infekuotumui ir infekcijos rūšiai nustatyti. Parodyta, kad pagal grafinius atvaizdus vištienos užterštumas bakterijomis nustatomas praejjus kelioms valandoms nuo jos infekavimo. Nagrinèta galimybè pagal kvapą diagnozuoti žaizdos infekciją ir infekcijos tipa klinikinèmis salygomis. 